\title{
Inside Productivity of Microcredit in Bangladesh: A surgical Analysis
}

\author{
Md. Mahmudul Alam* \\ PhD Student \\ Institute for Environment and Development (LESTARI) \\ National University of Malaysia \\ Selangor, Malaysia \\ E-mail: rony000@gmail.com \\ Rafiqul Islam Molla \\ Former, Specialist in Economics \\ Faculty of Business and Law \\ Multimedia University \\ Melaka, Malaysia \\ Email: rimolla@gmail.com
}

* Corresponding author

\section{Citation Reference:}

Alam, M.M., and Molla, R.I. 2012. Inside Productivity of Microcredit in Bangladesh: A Surgical Analysis, Asian Economic and Financial Review, Vol. 2(3), pp. 478-490. (online) http://www.aessweb.com/download.php?id=1405

This is a pre-publication copy.

The published article is copyrighted by the publisher of the journal. 


\title{
Inside Productivity of Microcredit in Bangladesh: A surgical Analysis
}

\begin{abstract}
Microcredit typically refers to petty collateral-free credits given to groups of poor members in the society for their socioeconomic emancipation. It is claimed to be an effective tool for enhancing income of the poor primarily through creation of self-employment opportunities for them in a variety of small economic activities. However, in this survey of microcredit borrowers in Bangladesh it is found that when self-employed family labor is paid wages at market rate, under the framework of economic-profit counting, economic productivity of credit for about $48 \%$ of the borrowers is not enough to support payment of any interest. Similarly its social productivity in terms of job creation and women's empowerment at family level is also found to be low and marginal. Even then about $90 \%$ of the borrowers prefer taking microcredit from microfinance institutions (MFIs) even at exorbitantly high interest rate, ostensibly to avoid compromising their socio-political rights and potentials at the hands of the local moneylenders or friends and relatives if credits are obtained from them. They see microcredit as a means of socio-political empowerment of the economically weak and underprivileged members of the society. As such they regard it as a more credible social than economic program.
\end{abstract}

Key Words: Grameen Bank, microcredit, microenterprise, subsistent, poverty alleviation, economic-profit counting, accounting-profit counting, stereotype, empowerment

\section{INTRODUCTION}

Because of its extensive uses microcredit is a household word in Bangladesh. It deals with very small scale financial services like savings and loans for productive purposes like investment in productive activities and for non-productive purposes like meeting emergencies, spending for day-to-day living, etc. Credits are usually given to groups of individuals or village organizations without any collateral. It applies the principle of jointliability (peer-pressure) to enforce loan repayment. Microcredit has launched a challenge to 
the formal financial system which virtually denies the scope of economic emancipation of the poor. By creating an avenue for the poor to have access to modern credit for economic growth and human development, microcredit has opened a scope for promoting poverty alleviation and reducing income inequalities in the society. Yunus (1993) claims that microcredit program is an effective tool for enhancing income of the poor primarily through creation of self-employment opportunities for them in a variety of informal economic activities. It is claimed that microcredit has been effectively serving the financial needs of the poor who now have access to necessary credit for building economic enterprises, according to their available skills, to earn better income (Grameen Bank, 2010; Grameen Fund, 2010). Its importance as a strategy of poverty alleviation has been prioritized since 2007 when Grameen bank and its founder Prof. M. Yunus jointly won the Noble Prize for pioneering the microcredit program. It is now practiced in a large number of countries in the world.

Bangladesh is called the land of microcredit. It is noted for high growth rate of microcredit borrowers. It has 21.77 million total borrowers or 15.55 million effective borrowers after adjustment for multiple borrowing (PKSF, 2006). Microcredit is delivered typically through nongovernment organizations (NGOs) at exorbitantly high interest rates ranging from $25-65 \%$ (Third Sector, 2004). Whereas, the credit providing institutions obtain bulk of their loans from Bangladesh bank at 4-5\% interest rate and even at lower rates from international donors. It may be also noted that the normal banking sector charges interest at only $10-12 \%$ for loans to the small and cottage industries (Bangladesh Bank, 1997).

The effectiveness, productivity, and high interest rate charges of microcredit in the country have been highly criticized by many scholars, development practitioners, and politicians. Various empirical studies suggest that microcredit programs have in fact 
generated a positive change in the income of beneficiaries, but this change has been marginal. In fact, for the large number of the borrowers virtually there has been no change in their economic and social status (Chavan and Ramakumar, 2002; Ahmad, 2007; Molla et al., 2008). Remenyi (2000) observes that it will be too much to regard microcredit as a panacea for entrenched poverty in the developing world. The current finance minister of Bangladesh, however, recently observed that even though microcredit could not possibly pull people out of poverty but it gave them a way for living (Star Business Report, 2009). Thus, the role of microcredit in reducing poverty and improving socioeconomic wellbeing of the poor in Bangladesh is very controversial with contradictory results from different researches. For this study, therefore, it is hypothesized that microcredit in Bangladesh suffers from low economic productivity, and it is a more credible social than economic program. For testing this hypothesis this study has made an extensive survey of microcredit borrowers throughout the country.

The most important significance of this study is that its findings will help the policy makers and development planners in the country, firstly, to have a closer view and clear understanding of the scopes and limitations of microfinance as an economic institution for the real world credit borrowers and credit providers and, secondly, to formulate appropriate policies and action strategies for effectively using the microcredit scheme as a means of poverty alleviation, by promoting self-employment based subsistent enterprises, and as a growth generating tool, through promotion of business like micro enterprises.

\section{PLAN AND METHODOLOGY OF THE STUDY}

It is a descriptive research using primary data collected through a survey of current microcredit borrowers in Bangladesh. In the absence of full knowledge on the structure 
and distribution of the population of microcredit borrowers in the country, random sampling as representative sampling is neither possible nor desirable. Moreover, in many situations random sampling is not effective, or cost effective, for serving the purpose for which sample data are collected. Purposive or judgment sampling is effectively used in such cases. Accordingly, a judgment sampling plan was thought more effective and appropriate for this survey. Data were collected from a sample of 555 current microcredit borrowers all over the country during January-April, 2008. Samples were selected from urban $(32.4 \%)$, semi-urban $(27.2 \%)$, and rural $(40.4 \%)$ areas covering 61 sample subdistricts of 28 sample districts in the 7 administrative divisions of Bangladesh by judgment to ensure that micro borrowers of different sizes engaged in various categories of economic operations in urban, semi-urban, and rural settings are adequately represented for analysis (Annexure 1).

Data have been analyzed basically under a descriptive model using tabular analyses. Simple statistical tools like averages, percentages, ratios, etc. have been used for a surgical analysis of the socioeconomic productivity of microcredit in terms of income generation, job creation, social empowerment, and total wellbeing of the borrowers in order to evaluate the economic, social, and political role microcredit plays in the borrowers' life management. However, it has been supplemented by an econometric analysis. A Cobb-Douglas type production function has been used for this purpose. Since in some cases Y (net-worth) has negative values, it is not possible to use the log form. Therefore the following linear production model has been used (Alam and Molla, 2011):

$$
\mathrm{Y}_{\mathrm{i}}=\Omega_{\mathrm{i}}+\alpha_{\mathrm{i}} \mathrm{K}_{\mathrm{i}}+\beta_{\mathrm{i}} \mathrm{L}_{\mathrm{i}}+\varepsilon_{\mathrm{i}}
$$

Where, $\mathrm{Y}=$ Year end net-worth (in Tk) before paying family labor and interest cost 
$\mathrm{K}=$ Full year equivalent capital/ investment $(\mathrm{Tk})$

$\mathrm{L}=$ Total labor hours

$\Omega=$ Constant

$\alpha, \beta=$ Coefficient

$\varepsilon=$ Error term

For computation of elasticity the following formula has been used:

$\Phi=\zeta *(\omega / \delta)$

Where, $\Phi=$ Elasticity value

$\zeta=$ Coefficient of respective variable $-\alpha_{\mathrm{i}}$ or $\beta_{\mathrm{i}}$

$\omega=$ Mean of respective independent variable $-\mathrm{K}_{\mathrm{i}}$ or $\mathrm{L}$

$\delta=$ Mean of the dependent variable $-Y_{\mathrm{i}}$

$\mathrm{i}=$ Respective variable

In measuring the productivity or surplus generated from the use of microcredit, researchers in previous studies avoided the use of economic-profit counting method which takes into consideration also the implicit costs like cost of self-employed family labor. Only the present researchers successfully used this method in their pilot study in 2006 (Molla et al., 2008). Accordingly, in this study the economic-profit counting, instead of accounting-profit counting, method has been used. Application of this approach may be claimed as a net addition to the literature on research methodology in this field.

\section{FINDINGS AND DISCUSSIONS}


Features of important findings of the survey are listed in Table 1 for easy reference, analysis, and discussion. The raw data were processed and analyzed in other publications (Molla, 2010; Alam and Molla, 2011; Alam and Molla, 2012b).

Table 1: Features of important findings of the survey of microcredit borrowers in Bangladesh, 2008

\begin{tabular}{|c|c|}
\hline Important Features & Data and Findings \\
\hline \multirow[t]{2}{*}{ Sample size } & $\begin{array}{l}\text { Total sample : } 555 \\
\text { Subsistent borrowers : } 490(88.3 \%)\end{array}$ \\
\hline & $\begin{array}{l}\text { Microenterprise borrowers : } 65(11.7 \%) \\
\text { Beyond subsistence level operation using self- employed } \\
\quad \text { labor : } 20 \\
\text { Beyond subsistence level operation using self- employed } \\
\quad \text { and hired labor : } 33 \\
\text { Subsistence level operation but using self-employed and } \\
\quad \text { hired labor : } 12\end{array}$ \\
\hline Age below 30 years & $42 \%$ of borrowers \\
\hline Literacy : Literate & $53.5 \%$ of borrowers \\
\hline Number of current credits per borrower & $\begin{array}{l}\text { Single credit: } 71.7 \% \text {; } \\
\text { Multiple credits : } 28.3 \% \text { ( } 2 \text { loans } 22.7 \% ; 3 \text { and } \\
\text { more loans } 5.6 \% \text { ) }\end{array}$ \\
\hline Number of credits taken over time & 13.8 per borrower \\
\hline Amount of current credit per borrower & $\begin{array}{l}\text { Tk } 15,342 \text { (Tk5,000-20,000 - for } 82 \% \text { borrowers) } \\
\text { exchange rate : US } \$ 1=T k 70\end{array}$ \\
\hline Desired credit requirement & Tk 20,000 - $69 \%$ borrowers reported \\
\hline $\begin{array}{l}\text { Grmeen's permissible credit size per } \\
\text { borrower }\end{array}$ & Tk 5,000-12,000 \\
\hline $\begin{array}{l}\text { Use of credit fund entirely for } \\
\text { consumption }\end{array}$ & $15 \%$ borrowers \\
\hline Use of credit fund for investment & $\begin{array}{l}\text { Full amount- } 56 \% \text {; partial- } 29 \% \text {; with initial additional } \\
\text { fund }-28 \% \text {; topped-up fund during the year }-21 \%\end{array}$ \\
\hline $\begin{array}{l}\text { Amount of full-year equivalent current } \\
\text { investment per borrower }\end{array}$ & Tk 16,424 (credit constitutes $81 \%$ of it) \\
\hline $\begin{array}{l}\text { Investment in small scale production } \& \\
\text { trade in agric, livestock \& fishery items }\end{array}$ & $48 \%$ of the borrowing investors \\
\hline Cycle of business return & $\begin{array}{l}\text { A day or a week - for } 69 \% \text { borrowers; a month or a year } \\
- \text { for } 28.5 \% \text { borrowers }\end{array}$ \\
\hline
\end{tabular}


Amount of annual return on investment per borrower

Inability to pay any interest

Ability to pay above $60 \%$ interest with capital repayment

Ability to pay more than $25 \%$ interest with capital repayment

Elasticity of Productivity

Return to Scale

Job creation (self-employment) per Tk 1000 microcredit investment for a year

Economic wellbeing of the households after using microcredit - Improved

Use of microcredit by women borrowers themselves

Family level empowerment of women borrowers
Tk 33,654 after paying self-employed labor at minimum wage rate - Tk8 for man; Tk 5 for woman per hour

Tk. 9,341 after paying self-employed labor at market wage rate - Tk17.8 for man; Tk12.4 for woman per hour

$7.6 \%$ after paying self-employed labor at minimum wage rate

$48 \%$ after paying self-employed labor at market wage rate

$75.1 \%$ after paying self-employed labor at minimum wage rate

$33.8 \%$ after paying self-employed labor at market wage rate

$41 \%$ after paying self-employed labor at market wage rate

Microcredit : $0.44-0.46$

Labor: 0.49 - 0.54

Decreasing for subsistent enterprise

31.7 labor-days

$86.50 \%$ borrowers reported

$10.6 \%$ of the women borrowers

Increased : $39.4 \%$ women borrowers; no change $36.5 \%$ women borrowers

Source: Molla, 2010; Alam and Molla, 2011

\subsection{Size and Use of Credit Funds}

Microcredit borrowers are small producers or petty traders or small shopkeepers like tailoring shop, vegetable stall or peddling, fruits stall or peddling, fish stall or peddling, carpenter shop, hair cutting saloon, etc. About $48 \%$ of them are primarily engaged in small scale production or selling of agricultural, forestry, livestock, and fisheries products. They use the credit fund as capital for their different economic operations as well as for consumption purposes. Amount of capital required to start a small economic operation varies according to the type of operation. Therefore, in some cases the amount of the microcredit may not be enough to start the operation; in some other cases additional amount is required at the later 
stage after the start of the business. In such cases the investors have to top up the capital from their own resources or by taking one or more loans from other microcredit lending institutions. In some other cases the entire credit amount may not be required or used at the start of the operations. In such cases the borrowers often use the unused amount for nonproductive purposes.

From the survey it is found that about $15 \%$ of the borrowers used the credit fund entirely for consumption (non-productive) purposes and the remaining borrowers used the entire or part of the credit fund for productive purposes. About $56 \%$ of them used the entire amount and about $29 \%$ used only part of the amount of the credit in productive operations (Table 2). About $28 \%$ of all the borrowers have to top-up the loan fund with personal fund or another loan from other microcredit lender to start the business. On top of that, about $21 \%$ of all the borrowers are found to have invested additional fund during the year similarly either from personal source or from credits obtained from other microcredit providers.

Table 2: Utilization of microcredit fund and own fund (frequency of borrowers)

\begin{tabular}{lcc}
\hline \multicolumn{1}{c}{$\begin{array}{c}\text { Heads of } \\
\text { uses of credit fund }\end{array}$} & $\begin{array}{c}\text { At the Starting } \\
\text { of the Operation }\end{array}$ & $\begin{array}{c}\text { Additional Investment } \\
\text { during the Year* }\end{array}$ \\
\hline $\begin{array}{l}\text { Consumption } \\
\text { Investment- Part Amount }\end{array}$ & $\begin{array}{c}\text { (162 (14.8\%) } \\
\text { Investment- Full Amount }\end{array}$ & $37(6.7 \%)$ \\
$\begin{array}{l}\text { Investment- Full Credit fund } \\
\text { and Additional Amounts* }\end{array}$ & $156(28.1 \%)$ & $46(8.3 \%)$ \\
\hline Total & 555 & $36(6.5 \%)$ \\
Full-year equivalent total investment per credit-borrower investor : Tk 16,424 \\
\hline$*$ Additional amount for investment comes from personal and/or additional borrowing from \\
other lending organizations
\end{tabular}

Source: Survey data

\subsection{Credit Requirements and Multiple Borrowing}


About $64 \%$ of the borrowers have total investments (borrowed and own funds) up to Tk 20,000 or below. On the other hand, over two-thirds (i.e. $69 \%$ ) of them indicate that they need credit up to Tk 20,000. Therefore, it reveals that many borrowers need more credit fund for effective operation of their economic enterprises. In an earlier study Sharma (2002) similarly observed that the current amount of microcredit was very inadequate as capital to initiate any reasonable business or expand a business. To find the required additional fund the borrowers generally rely on their personal source or other microcredit lending institutions. A borrower can take loans simultaneously from different MCIs or from different branches of the same MCI. In this study over $28 \%$ of the borrowers are found to have multiple loans (2-3 or more) from 2-3 or more microcredit institutions to meet their business capital requirements. Over $37 \%$ of the borrowers report that they are encouraged by other MCIs to take additional loans from them. PKSF (Palli Karma-Sahayak Foundation) is also aware of this multiple credit practices.

\subsection{Borrowers' Business Return Cycle}

Repayment installments for microcredit start from the subsequent week of the loan disbursement. For many economic activities it is nearly impossible to generate significant return within a week after initiating an investment, for example, investment in agriculture and livestock. In case of only $69 \%$ of the borrowers under study there are daily or weekly return from microcredit invested activities. But in $28.5 \%$ cases, returns from investment start coming after 1-12 months. As a result it has not been possible for many of these borrowers to pay the initial repayment installments from the revenue generated from the investment of the credit fund. Other researches also found that most of the clients did not pay the initial repayment installments from the generated revenue (or increase in income) but usually by 
obtaining funds through another credit or by selling their domestic animals, trees etc (Ahsan and Rahaman, 2006).

\subsection{Economic Productivity of Microcredit}

Interest rate for microcredit ranges from $25-65 \%$ while the formal banking sector charges interest only at $10-12 \%$ for the small and cottage industry sector. The lenders argue that microcredit's delivery and supervision cost is very high. Therefore, charging of high interest is required to cover the high delivery costs. They also claim that the high rate of growth of the borrowers, even at this high interest rate charges, indicates that the microcredit is highly productive and profitable for the borrowers making them able to easily pay the high interest.

Grameen Bank reportedly charges nominal interest at 22.45 percent which comes to effectively $30.5 \%$ because of the system of weekly repayment of installments (Ahmad, 2007). Another research found that the exorbitantly high rates of interest charged by the credit providers are in fact pushing the borrowers to sell their self-employed family labor at or below subsistence rate of wages (Molla et al., 2008). When analyzing the benefits of the borrowers and effectiveness of the microcredit programs, the lenders take resort to calculation of accounting-profit of borrowers' business enterprises and ignore implicit costs under the plea that the opportunity cost of labor is near zero in the country. This plea is certainly not tenable even under the assumption of a less than full-employment. It will, in fact, amount to going back to the concept of distressed selling of labor (much like slavery) of the medieval age and making microcredit a self defeating strategy for poverty alleviation (Molla and Alam, 2007). Therefore interest rate for microcredit should be consistent with its true productivity which should be measured taking into consideration implicit cost of selfemployed family labor, under the framework of economic-profit counting. 


\subsubsection{Revenue and net worth of investment by economic-profit counting}

Borrowers' average full-year equivalent investment during the study year is Tk 16,424; and microcredit constitutes $81 \%$ of it. If we impute a minimum labor cost for borrowers' self employment, the rate of return on investment (ROI) is reduced from $430 \%$ to $254 \%$; and this rate declines to $28 \%$ if market rate of labor cost is applied for self-employed/family labor (Table 3).

Table 3: Return and net worth of microcredit investments

\begin{tabular}{llll}
\hline \multicolumn{1}{c}{$\begin{array}{c}\text { Net Worth and } \\
\text { Return on Investment }\end{array}$} & $\begin{array}{l}\text { Before paying } \\
\text { Family labor } \\
\text { and interest }\end{array}$ & $\begin{array}{l}\text { After paying } \\
\text { family labor at } \\
\text { minimum wage } \\
\text { rate, but before } \\
\text { paying interest* }\end{array}$ & $\begin{array}{l}\text { After paying } \\
\text { family labor at } \\
\text { market wage } \\
\text { rate, but before } \\
\text { paying interest** }\end{array}$ \\
\hline Average of borrowers' Net Worth or Surplus (Tk) & 52,282 & 33,654 & 9,341 \\
Average of borrowers' Investment (Tk) & 16,424 & 16,424 & 16,424 \\
Average of borrowers' ROI (\%) & $430 \%$ & $254 \%$ & $28 \%$ \\
\hline
\end{tabular}

* Minimum labor cost per hour=man @ Tk 8, woman @ Tk 5

**Standard labor cost per hour at market rate=man @ Tk 17.8, woman @ Tk 12.4

Source: Survey data

But behind this scenario of the average return on investment lies the truth of the deplorable situation. When minimum cost for family labor is charged the ROI for $7.6 \%$ of the borrowers become negative and when the family labor cost is charged at market wage rate the ROI for $47.6 \%$ of the borrowers become negative (Table 4). It therefore suggests that for about $48 \%$ of the borrowers microcredit investment is not productive to generate enough revenue for payment of any interest if the market wage rate is charged for self employed / family labor; but it is unproductive only for about $8 \%$ of them if minimum wage is charged for family labor. Therefore it appears that many (as many as 48\%) of the borrowers compromise wages for their self-employed labor (family labor) to find microcredit productive 
to command high interest payment. If minimum wages is paid for the family labor, as many as $75 \%$ of the borrowers will have annual rate of net return on investment enough for payment of interest @ 60\% and above. Whereas, if market rate of wages is paid for them only $34 \%$ of them will have enough return on investment to pay that high rate of interest. But the $48 \%$, and more particularly the $8 \%$ borrowers, are the critical groups whose family labor wages are being seriously compromised to make it possible to pay high interest and make microcredit credible in the eyes of the society even at that high rate of interest charges.

Table 4: Borrowers by interest payment capability from business returns (frequency)

\begin{tabular}{lcc}
\hline Interest Rate $(\%)$ & $\begin{array}{c}\text { Ability after paying family labor @ } \\
\text { minimum wage rate* }\end{array}$ & $\begin{array}{c}\text { Ability after paying family labor @ } \\
\text { market wage rate }\end{array}$ \\
\hline Negative & $36(7.6 \%)$ & $228(48.2 \%)$ \\
Above 0 and up to 10 & $24(5.1 \%)$ & $25(5.3 \%)$ \\
Above 10 and up to 25 & $15(3.2 \%)$ & $25(5.3 \%)$ \\
Above 25 and up to 40 & $20(4.2 \%)$ & $15(3.2 \%)$ \\
Above 40 and up to 60 & $23(4.9 \%)$ & $20(4.2 \%)$ \\
Above 60 & $355(75.1 \%)$ & $160(33.8 \%)$ \\
\hline Total & $473 * *$ & $473 * *$ \\
$*$ Considering minimum labor rate: male @ Tk 8 , and female @ Tk 5 per hour. \\
$\wedge$ Considering standard/ market wage rate: man @ Tk 17.8, and woman @ Tk 12.4 per hour \\
$* * 1$ person who was holding the credit fund at hand and the 81 non-investment cases are not included \\
here
\end{tabular}

Source: Survey data

Thus the harsh criticism against the high interest rate of microcredit is very much real. ${ }^{1}$ There is an urgent need for this to be addressed seriously. The problems of the critical and vulnerable groups of $48 \%$ borrowers must be addressed and resolved urgently. Because of the fact that these poor borrowers deal with very low-return economic opportunities, it is unreasonable to believe that they can pay such high interest. It is important to note that $48 \%$ of the borrowers who have low productivity and are deprived of the market rate of wages for their self-employed labor remain vulnerable to default repayments. As a result $22.9 \%$

\footnotetext{
${ }^{1}$ Consequently, the government of Bangladesh recently set $27 \%$ as the upper limit of chargeable interest rate on microcredit.
} 
borrowers report that they are not able to pay their repayment installments from income of microcredit invested economic operations.

\subsubsection{Econometric measurements of productivity}

Using the production function (equation-1) the econometric analysis of productivity of labor and microcredit similarly suggests that labor is relatively more productive than microcredit under both the assumptions that in subsistent enterprises a) male and female labors are equally productive, and b) female labor is relative less productive and can claim only a lower wage rate. The analyses reveal that a $1 \%$ increase in labor hour or labor cost increases the net-worth by $0.54 \%$ or $0.49 \%$, and a $1 \%$ increase in microcredit investment increases the networth by $0.44 \%$ or $0.46 \%$ (Table 5). It is also found that the subsistent enterprises have reached the stage of decreasing return to scale supporting the fact that microcredit is primarily a program of poverty alleviation. It has limited scope to be used as a growth generating tool.

Table 5: Productivity of microcredit and labor

\begin{tabular}{|c|c|c|c|c|c|c|c|}
\hline Measurement & Variable & $\begin{array}{l}\text { Coefficient } \\
\qquad(\alpha, \beta)\end{array}$ & Elasticity & $\begin{array}{l}\text { Return to } \\
\text { Scale }\end{array}$ & $\begin{array}{c}\mathrm{P} \\
\text { value }\end{array}$ & $\mathrm{R}^{2}$ & $\begin{array}{c}\text { Sample } \\
\text { Size }\end{array}$ \\
\hline \multirow{3}{*}{ Labor in Hour ${ }^{\text {a }}$} & $\Omega$ & -1186.80 & & & 0.65 & & \multirow{6}{*}{$524^{\$}$} \\
\hline & $\mathrm{K}$ & $1.13 *$ & 0.44 & 0.98 & .000 & $0.53^{\wedge}$ & \\
\hline & $\mathrm{L}$ & $12.42 *$ & 0.54 & (decreasing) & .000 & & \\
\hline \multirow{3}{*}{$\begin{array}{l}\text { Labor in value } \\
{\text { (General })^{b}}^{b}\end{array}$} & $\Omega$ & 2146.01 & & & 0.41 & & \\
\hline & $\mathrm{K}$ & $1.18^{*}$ & 0.46 & 0.95 & .000 & $0.507^{\wedge}$ & \\
\hline & $\mathrm{L}$ & $0.57 *$ & 0.49 & (decreasing) & .000 & & \\
\hline
\end{tabular}

"Denotes significant at $1 \%$ significance level

${ }^{\wedge}$ In analyzing cross-sectional data R2 value of 0.53 or 0.51 is considered acceptable

$\$$ Includes 51 borrowers who have invested in multiple business activities $(473+51=524$ samples $)$

${ }^{a}$ Under the assumption there is no difference between male and female labor in terms of productivity

${ }^{\mathrm{b}}$ Labor hours weighted by market established standard wage rates for male and female reflecting the society's perception that female labor is relatively less productive to command a lower wage rate.

\subsection{Social Productivity of Microcredit}




\subsubsection{Job creation}

A fundamentally important claimed role of microcredit is job creation through creation of opportunities for self-employment. This study finds that for each Tk 1,000 microcredit invested for a year a 31.7-mandays of job is created (Table 6). In other words, for creation of a full-time annual self-employed job (310 labor-days of actual work in a year) it requires an investment of nearly Tk 10,000 microcredit fund. Though, in an earlier (pilot) study this was found to be Tk 12,000 (Molla et al., 2008). It would be certainly interesting and desirable to study the job creation ability of other types of investments in the country. But we leave it for the future researchers to address it.

Table 6: Job creation per Tk 1,000 microcredit investment for a year

\begin{tabular}{lcc}
\hline Types of Labor & Labor Hours & Labor Days** \\
\hline Average Job Creation for Man & 200.77 & 28.68 \\
Average Job Creation for Woman & 25.06 & 3.58 \\
\hline Total Job Creation* & 221.88 & 31.70 \\
\hline$*$ Average of the jobs created by individual borrowers \\
$* *$ Full-time labor day is considered as 7 working hours per day \\
\\
$\quad$ Source: Survey data
\end{tabular}

\subsubsection{Household economic wellbeing}

Findings of several studies, to an extend support the general claim that microcredit program is an effective tool for increasing income of the poor through creation of self-employment in informal economic activities. World Bank's study on the impacts of microcredit program of the Grameen Bank indicates that access to credit by the poor has increased self-employment and rural wages (Pitt and Khandker, 1996). This has brought desirable impacts in terms of employment and production especially for women in the non-farm sector (Khandker, 1998). A study on rural poverty in Bangladesh by the Bangladesh Institute for Development Studies 
(BIDS) shows that microcredit recipients have higher rate of growth in per capita income compared to non recipients (Rahman et al., 1996). Microcredit, therefore, has brought large growth in non-farm income and thus total income gain at the village level. Likewise, $87 \%$ of the borrowers under survey have reported that they have experienced economic improvements after joining the microcredit program. This economic improvement is, however, not necessarily due to economic productivity of microcredit itself, but mostly because microcredit serves as a facilitator for self-employment opportunities and other socioeconomic wellbeing. It also means that for most of the borrowers credit, either from MFIs or from traditional moneylenders and other sources, is a necessary factor for their economic improvements through self-employment opportunities. About $30 \%$ borrowers believe that after taking 1-3 more loans they will not require any further credit. This may suggest that microcredit is an effective facilitator for socio-economic betterment of the borrowers, even when its economic productivity is not found so satisfactory for about $48 \%$ of the borrowers.

\subsubsection{Women empowerment}

Microcredit is known as a most significant intervention in the fight against poverty for the twenty-first century (Rahman, 1998). But the thrust of the movement especially has been to engage poor women not only to alleviate poverty but also to increase their access to resources and enhance their power in household decision-making (Sundram, 2001). It is assumed that in the poor families women's increasing access to micro-finance will enable them to make a greater contribution to household income and this, together with other interventions to increase households' well-being, will enhance their dignity and facilitate their playing greater role in the society. This will increase women's self-confidence and status within their families. Different researches suggest that empowerment of women brings significant improvement in their participation in household decision making, family planning, children 
survival rate, health and nutrition and children education, especially girls' education (Steele, Amin and Naved, 1998). With this end in view microcredit is mostly given to the women of the rural poor families. But in reality women are found to be only the media for obtaining the credit; in most cases male members of their families actually take decisions and use the fund. It is found that actually only $10.6 \%$ of the women borrowers use the credit by themselves. In the remaining $89 \%$ cases the male members of their families make decisions and use the loan fund. Similarly, borrowers' assessment on empowerment is found mixed and unclear - about $39 \%$ claim that their status and authority in the family have improved, but about $37 \%$ feel that there has been no change in their status and authority in the family.

\subsection{Microcredit is a More Credible Social than Economic Program}

Interest rate for credit is expected to be consistent with the economic productivity and profitability of the credit. Judging from this consideration, interest rate for microcredit is found unjustifiably high for most $(64 \%)$ of the borrowers. However, it is interesting to note that about $57 \%$ of the borrowers surveyed do not think that interest rate charged for microcredit is unreasonably high; only about $36 \%$ believe otherwise. Micro borrowers feel socially and politically better with institutional credit obtained from MFIs. Because, in the first place interest rate charged by the local moneylenders may not be less than that is charged by the microcredit providers. In addition, the poor borrowers generally lose a great deal of their political and social rights and status in the hands of these moneylenders (or friends and relatives) when they borrow money from them. (Traditionally, lending money, even on payment of high rate of interest, is regarded as a favour done to the borrower. As a result, the borrowers remains highly grateful to the lenders. This makes the borrowers become subservient and under domination of the credit lenders). It appears that the micro borrowers give priority to social and political empowerment over the economic gains. As a result, they 
prefer to borrow from microfinance institutions even when their interest rates often could be higher than the interest rates charged by local moneylenders. That is why as many as $48 \%$ of the microcredit borrowers are found willing to sacrifice or compromise their standard market wages for their self-employed labor. They see microcredit as a saver of their social and political rights and status. They see it as a more credible social than economic program (Molla and Alam, 2011).

\subsection{Limited Scopes for Promoting Microenterprises}

Initially, decades ago, microcredit was thought to be a growth generating tool in the pursuit of rural development. But now it is regarded basically as a tool for poverty alleviation. It is aimed at creating self-employment opportunities primarily for the poor female clients according to their individual survival skills. Accordingly a stereotyped delivery system is designed and used for promoting and supporting the survival and subsistent level economic activities of these clients (Alam and Molla, 2012a). Survey results suggest that to the extent that the activities are only at survival and subsistent level, this standardized system is generally working. However, since the individual survival skills are different for different borrowers and they are pursuing different activities requiring credit supports differently, this stereotyped system may not be so effective for all the borrowers. This is particularly true for the microeconomic enterprises which are growth yielding small business like beyond subsistent level economic operations. This kind of operations has a different nature of credit needs. Survey result shows that $11.7 \%$ of the microcredit borrowers belong to this kind of potential or growing microentrepreneurs. It also shows that microcredit's standardised delivery system, particularly in respect of gender preference, loan size, loan disbursement and repayment schedules, is highly inadequate and limiting factor for effectively serving and promoting the microenterprises which require a more flexible credit package. It, therefore, 
suggests that a methodological modification is necessary to accommodate flexibility in microcredit delivery system to make it able to work for microenterprises as well. For promoting this kind of enterprises, its attachment to and preference for female clients must be relaxed. In fact, in the context of Bangladesh society, male entrepreneurs should be preferred in these business like enterprises. In business like economic activities generally women are not found culturally and traditionally effective entrepreneurs and credit users in Bangladesh. Social customs and religious traditions do not encourage and respect women in such business like economic activities. As a result, in most cases the women collect the credit as borrowers (since the credit providing institutions prefer to grant credit to women) but generally the male members of their families make the decisions and use the credit fund (Goetz and Gupta, 1996). From the survey it is found that only $10.6 \%$ of the women borrowers have actually used the credit by themselves. In the remaining $89 \%$ cases the male members of their families have operated the loan fund (Table 7)

Table 7: Users of Credit Borrowed by Women Clients (frequency)

\begin{tabular}{lrr}
\hline Loan User & All Borrowers & Microenterprises Borrowers \\
\hline Self & $57(10.6 \%)$ & $6(9.5 \%)$ \\
Male Family Members & $453(84.4 \%)$ & $56(88.9 \%)$ \\
Third Party & $11(2.0 \%)$ & $1(1.6 \%)$ \\
No Response & $16(3.0 \%)$ & 63 \\
\hline Total & 537 & \\
\hline * 18 cases out of 555, the microcredit clients are male and 2 cases out of 65, the microcredit clients &
\end{tabular}

\section{Source: Field Survey}

A variety of reasons have been mentioned by the respondents (women borrowers) for their dependence on men for economic operations. The most frequently reported ones are : a) inability and lack of skill of the women borrowers in doing business like outside-home 
activities, b) more and better investment opportunities in man relevant activities, c) male dominated family structure where male members maintain and control family, d) social environment and custom where business activities are considered to be men's job, and e) women are not expected and respected in the domain of men's activities (business like activities). Therefore the preference for women as clients for credit is found as a strong methodological limitation of the microcredit delivery system for promoting microenterprises.

The need for a separate credit package for microenterprises has been recognized by Grameen and other microcredit institutions in the country. As a matter of fact Grameen Fund (2010) has undertaken a separate project for providing loans to microenterprises, but under very restricted conditions. Unfortunately, because of these restricting conditions it has turned out to be almost like a traditional commercial loan scheme. Thus, most of the potential microenterprises are not able to enjoy the services and benefits of that loan program.

\section{CONCLUSIONS}

Microcredit has gained global recognition as a successful scheme for poverty alleviation. However, a surgical economic analysis reveals that its net economic benefit to the borrowers is at best marginal. About $48 \%$ of the borrowers have to compromise their normal wages for self-employed labor only to be able to pay the high interest for the credit. An econometric analysis of the productivity of labor and microcredit also suggests that labor is relatively more productive than microcredit. Similarly, in terms of job creation it has a limited success. It requires investment of about Tk. 10,000 credit fund for a year to create one annual full-time self-employed job. Similarly its success in terms of improvement of women borrowers' empowerment at the family is mixed and unclear. Most of these findings on the shortcomings 
of microcredit management in Bangladesh are found consistent with, and supportive of, the results of earlier studies.

However, as large as $90 \%$ of the borrowers (including the $36 \%$ who consider interest charges for microcredit as very high) appreciate and feel comfortable with microcredit from the MFIs even at so high interest rate seemingly to avoid compromising their socio-political rights and potentials at the hands of the local moneylenders or relatives if they obtain the credits from them. They see microcredit as a savior and protector of their socio-political rights and scopes. Thus, in the game of political economy of credit for the poor, they see microcredit as a means for enhancing and protecting the socio-political status of the low income and distressed people in the society. Microcredit borrowers, accordingly, appraise it as a more credible social than economic institution.

\section{REFERENCES}

Ahmad, Q.K. (ed.). 2007. Socio-Economic and Indebtedness-Related Impact of Microcredit in Bangladesh. Dhaka: UPL Publications.

Ahsan, M.K. and Rahaman, M.Z. 2006. Recovery Rates of Micro-Credit: A Study on Rural Women Participators. Journal of Business Studies, Southeast University. Vol. 2 (1).

Alam, M.M. and Molla, R.I. 2011. Inside Story of Microcredit in Bangladesh: An Empirical Investigation on the Role and Productivity, LAP Lambert Academic Publishing: Saarbrucken.

Alam, M.M., and Molla, R.I. 2012a. The Limitations of Microcredit for Promoting Microenterprises in Bangladesh, Economic Annals, Vol. 57(192), pp. 41-53. Retrieved on April 10, 2012. Available at [http://ea.ekof.bg.ac.rs/pdf/192/138.pdf]

Alam, M.M., and Molla, R.I. 2012b. Productivity and Efficiency Challenges of Microcredit Program in Bangladesh, Centre for Research and Publication at International Islamic University Chittagong (IIUC): Chittagong, Bangladesh. (forthcoming)

Chavan, P. and Ramakumar, R. 2002. Micro-Credit and Rural Poverty: An Analysis of Empirical Evidence. Economic and Political Weekly, Vol. 37(10), pp. 955-965.

Geotz, A.M. and Gupta, R.S. (1996). Who takes the credit? Gender, power, and control over loan use in rural credit programs in Bangladesh. World Development, Vol. 24(1), pp. 45-63.

Grameen Bank. 2010. What is Microcredit? Retrieved on January 10, 2011. Available at [http://www.grameen-info.org/mcredit] 
Grameen Fund. 2010. Micro-Enterprise Loan Scheme. Retrieved on January 10, 2011. Available at [http://www.grameen-info.org/grameen/gfund/micro.html]

Khandker, S. 1998. Fighting Poverty with Microcredit: Experience in Bangladesh. Oxford: Oxford University Press.

Molla, R.I. and Alam, M.M. 2007. A Reflection on Economics of Microcredit Borrowing in Rural Bangladesh. Journal of Business and Behavioral Science. Vol. 18(1), pp. 227241.

Molla, R.I. and Alam, M.M. 2011. A Microcredit - A More Credible Social than Economic Program in Bangladesh. Economics Bulletin. Vol. 31(2), pp. 1095-1104. Available at [http://www.accessecon.com/Pubs/EB/2011/Volume31/EB-11-V31-I2-P102.pdf].

Molla, R.I., Alam, M.M. and Wahid, A.N.M. 2008. Questioning Bangladesh's Microcredit. Challenge: The Magazine of Economic Affairs, Vol. 51(6), pp. 113- 121.

Molla. R.I. 2010. Socioeconomic Productivity of Microcredit in Bangladesh: A Surgical Analysis, Working paper no. 2/2010, School of Local Development, University of Trento, Italy. Retrieved on January 10, 2011. Available at [http://www.unitn.it/files/download/11676/wp_2.2010_molla.pdf]

Pitt, M.M. and Khandker, S.R. 1996. Household and Intrahousehold Impact of the Grameen Bank and Similar Targeted credit Programs in Bangladesh, World Bank Discussion Paper No. 320, Washington D.C.: World Bank.

PKSF (Palli Karma-Sahayak Foundation). 2006. Maps on Microcredit Coverage in Upazilas of Bangladesh. Dhaka: PKSF.

Rahman, H.Z, Hossain M. and Sen, B. 1996. Dynamics of Rural Poverty in Bangladesh, Dhaka: BIDS.

Rahman, R. 1998. Micro-credit initiatives for equitable and sustainable development: who pays?, World Development, Vol. 27(1), pp. 67-82.

Remenyi, J. "Is there a 'State of the Art' in Microfinance". In Remenyi, J., \& Quinones, B. (Ed.) (2000) Microfinance and Poverty Alleviation Case Studies from Asia \& the Pacific, London: Pinter.

Sharma, S. 2002. Is micro-credit a macro trap? The Hindu, 25 Sep. Retrieved on January 10, 2011. Available at [http://www.hinduonnet.com/businessline/2002/09/25/stories/2002092500810900.htm ].

Star Business Report. 2009. Microcredit failing to lift people out of poverty. Retrieved on January $10,2011 . \quad$ Available at [http://www.bangladesh2day.com/newsfinance/2009/August/12/Microcredit-failingto-lift-people-out-of-poverty.php]

Steele, F., Amin, S. and Naved, R.T. 1998. The Impact of an Integrated Microcredit Program on Women's Empowerment and Fertility Behavior in Rural Bangladesh. Working Paper No. 115, Population Council, Policy Research Division, Washington.

Sundram, I. 2001. Self help groups: Challenges and opportunities. Social Welfare, Vol. 48(5), July, pp. 18-19.

Third Sector (A Bengali Monthly Magazine). 2004. Specialist- Abul Barakat's view about microcredit program that are run by NGOs. March, pp.24, Dhaka.

Yunus, M. 1993. Alleviation of Poverty is a matter of Will, Not a Means, Acceptance Speech on the Occasion of Receiving the Care Humanitarian Hall in Washington D.C., USA. 


\section{Annexure 1}

a. Distribution of samples by urban, semi-urban, and rural areas

\begin{tabular}{lc}
\hline Area & No. (\%) of Samples \\
\hline Urban & $180(32.4 \%)$ \\
Semi Urban & $151(27.2 \%)$ \\
Rural & $224(40.4 \%)$ \\
\hline Total & $555(100 \%)$ \\
\hline
\end{tabular}

\section{b. Distributions of samples by districts and sub-districts}

\begin{tabular}{|c|c|c|c|c|c|}
\hline District & Sub-District & $\begin{array}{c}\# \text { of } \\
\text { Sample }\end{array}$ & District & Sub-District & $\begin{array}{c}\text { \# of } \\
\text { Sample }\end{array}$ \\
\hline \multirow{5}{*}{ Feni } & Chhagalnaiya & 8 & Gopalganj & Gopalganj Sadar & 7 \\
\hline & Daganbhuiyan & 2 & \multirow{2}{*}{ Jhalokati } & Jhalokati Sadar & 11 \\
\hline & Fulgazi & 6 & & Rajapur & 10 \\
\hline & Parshuram & 7 & \multirow{2}{*}{ Khulna } & Dacope & 8 \\
\hline & Sonagazi & 5 & & Khulna Sadar & 19 \\
\hline \multirow{2}{*}{ Barguna } & Amtali & 11 & \multirow{3}{*}{ Lakshmipur } & Lakshmipur Sadar & 7 \\
\hline & Barguna Sadar & 11 & & Raipur & 6 \\
\hline \multirow{2}{*}{ Barisal } & Banaripara & 12 & & Ramganj & 7 \\
\hline & Barisal Sadar & 10 & \multirow{2}{*}{ Lalmonirhat } & Aditmari & 12 \\
\hline Bhola & Manpura & 8 & & Lalmonirhat Sadar & 9 \\
\hline \multirow{3}{*}{ Brahmanbaria } & Akhaura & 10 & \multirow{2}{*}{ Maulvibazar } & Rajnagar & 14 \\
\hline & Brahmanbaria Sadar & 11 & & Sreemangal & 11 \\
\hline & Sarail & 5 & Narayanganj & Araihazar & 10 \\
\hline \multirow{3}{*}{ Chandpur } & Chandpur Sadar & 8 & \multirow{2}{*}{ Noakhali } & Companiganj & 5 \\
\hline & Haziganj & 6 & & Senbagh & 7 \\
\hline & Shahrasti & 8 & \multirow{3}{*}{ Pabna } & Atgharia & 9 \\
\hline \multirow{3}{*}{ Chuadanga } & Alamdanga & 15 & & Chatmohar & 10 \\
\hline & Chuadanga Sadar & 11 & & Pabna Sadar & 12 \\
\hline & Damurhuda & 10 & \multirow{2}{*}{ Panchagarh } & Atwari & 11 \\
\hline \multirow{4}{*}{ Comilla } & Barura & 2 & & Panchagarh Sadar & 10 \\
\hline & Chauddagram & 6 & Pirojpur & Nesarabad & 5 \\
\hline & Comilla Sadar South & 6 & Rajbari & Baliakandi & 5 \\
\hline & Laksam & 14 & \multirow{3}{*}{ Rangpur } & Kawnia & 10 \\
\hline \multirow{3}{*}{ Dinajpur } & Birganj & 6 & & Mithapukur & 24 \\
\hline & Dinajpur Sadar & 13 & & Rangpur Sadar & 10 \\
\hline & Parbatipur & 10 & \multirow{2}{*}{ Sunamganj } & Chhatak & 10 \\
\hline Gaibandha & Gaibandha Sadar & 10 & & Sunamganj Sadar & 10 \\
\hline \multirow{3}{*}{ Jessore } & Abhaynagar & 9 & \multirow{2}{*}{ Sylhet } & Beanibazar & 8 \\
\hline & Chaugachha & 11 & & Sylhet Sadar & 8 \\
\hline & Jessore sadar & 10 & Tangail & Basail & 4 \\
\hline Gazipur & Kapasia & 5 & \multicolumn{2}{|c|}{ Total samples } & 555 \\
\hline
\end{tabular}

